\title{
Duplex PCR system for simultaneous detection of Neisseria gonorrhoeae and Chlamydia trachomatis in clinical specimens
}

\author{
K C Wong, B S W Ho, S I Egglestone, W H P Lewis
}

\begin{abstract}
Aims-To evaluate the use of a duplex polymerase chain reaction (PCR) assay for the simultaneous detection of Neisseria gonorrhoeae and Chlamydia trachomatis in clinical samples.

Methods-Genital swab specimens were obtained from both China (203 swabs) and Hong Kong (202 swabs). $N$ gonorrhoeae and $C$ trachomatis were detected in each specimen with a number of tests including enzyme immunoassays (IDEIA) and PCR assays using both single and double primer pairs. The primer pair for $\mathbf{N}$ gonorrhoeae was derived from the $c p p B$ gene on its cryptic plasmid and the PCR product was 390 base pairs long. For $C$ trachomatis, the PCR product was 473 base pairs long, resulting from amplification of a sequence in the common $7 \cdot 4$ kilobase plasmid present in all serovars. For $\boldsymbol{N}$ gonorrhoeae, PCR results were also compared with those obtained by culture and Gram's smear of the discharges.
\end{abstract}

Results-For the 203 specimens collected in China, similar numbers of positive results (177) were obtained by both Gonozyme and duplex PCR for the detection of $N$ gonorrhoeae. No discrepant results were found among the cultured specimens when Gonozyme and duplex PCR were compared. $C$ trachomatis was detected in 47 specimens by duplex PCR, but was detected in only 28 by IDEIA. Of the 202 Hong Kong specimens, 46 were positive for $\boldsymbol{N}$ gonorrhoeae, detected by both Gonozyme and duplex PCR; 34 were positive for $C$ trachomatis, 25 of which were detected by IDEIA and the remainder by duplex PCR.

Department of Health Sciences, Hong Kong Polytechnic, Hung Hom, Kowloon, Hong Kong $\mathrm{K} C$ Wong B S W Ho S I Egglestone W H P Lewis

Correspondence to: Mr K C Wong, Flat F, 19th Floor, Block 14, Sceneway Garden, Lam Tin, Kowloon, Hong Kong.

Accepted for publication 1 July 1994
Conventional diagnosis of gonorrhoea relies on culture and demonstration of intracellular

\section{Keywords: Duplex PCR, simultaneous detection.}

Gram negative diplococci in Gram smears of genital discharge or swabs. ${ }^{1}$ However, some Neisseria gonorrhoeae strains are susceptible to the concentrations of vancomycin used in the selective medium and hence the recovery rate is less than $100 \% .^{2}$ Rapid methods for diagnosing gonorrhoea using enzyme immunoassay (EIA)-for example, Gonozyme (Abbott Laboratories, Chicago, USA), have recently been evaluated and showed reasonably high sensitivity (87-98.5\%) and specificity (94$100 \%$ ) when compared with culture. ${ }^{3-5} \mathrm{~A}$ polymerase chain reaction (PCR) using primers derived from the integrated regions of the $c p p B$ gene of $N$ gonorrhoeae has also been described. ${ }^{6}$

Chlamydia trachomatis has gained widespread recognition because of its role in the aetiology of non-gonococcal urethritis. ${ }^{7}$ Conventional diagnosis of $C$ trachomatis relies on tissue culture. ${ }^{8}$ Although culture is reliable and specific, it is labour intensive, expensive, and not routinely available in most laboratories. With the advent of highly specific monoclonal antibody and immunological techniques, $C$ trachomatis can be detected in clinical material by direct immunofluorescence for the presence of elementary bodies. ${ }^{9}$ Recently, EIAs for the detection of $C$ trachomatis antigen have been developed. ${ }^{10-13}$ Although less sensitive than immunofluorescence, EIA has advantages in that it is less subjective as results are read by machine and do not require skilled microscopy techniques. The IDEIA enzyme immunosorbent assay (Dako Diagnostics Ltd., High Wycombe, UK) was reported to be more sensitive than other commercially available EIA kits $^{14}$ and even more sensitive than a DNA probe test kit, although IDEIA failed to distinguish between chlamydial species. ${ }^{15}$ Polymerase chain reactions for the detection of $C$ trachomatis have also been developed. ${ }^{16-18}$

This paper describes the development of a duplex PCR assay using one pair of gonococcal primers (Hol and Ho3) and one pair of chlamydial primers (CT2A and CT2B) for the simultaneous detection of the two organisms in one assay. As results of gonococcal culture are subject to many variable factors and culture of the swab specimens collected for this study was performed at different laboratories, culture results were not reliable enough to be used as 
standards. Although culture for $C$ trachomatis is reliable and specific, tissue culture facilities are not available in our laboratory. Because of this, the Gonozyme assay and IDEIA, which are reported to have reasonably high sensitivities and specificities for the detection of $N$ gonorrhoeae and $C$ trachomatis, respectively, were used as gold standards instead of culture. Furthermore, EIAs are independent of the presence of viable organisms and results are not affected by transportation.

\begin{abstract}
Methods
Between September 1991 and November 1992, 203 clinical specimens were collected from patients attending the Sexually Transmitted Disease clinic in Guangzhou, China. Urethral swabs from men and cervical swabs from women were collected if the patients were suspected of having gonorrhoea - that is, if a Gram smear of the discharge material showed intracellular Gram negative diplococci or numerous pus cells. Two swabs were collected from each patient. The first swab was used for gonococcal culture which was carried out in China. The other swab was inserted into an Abbott's enzyme immunoassay transport medium tube and maintained at $-20^{\circ} \mathrm{C}$ except during transport. Each swab was then suspended in $1 \mathrm{ml}$ of specimen dilution buffer (supplied with the Gonozyme kit), $0.2 \mathrm{ml}$ of which was used for the Gonozyme assay, $0.5 \mathrm{ml}$ for DNA extraction for the PCR assay, and $0.2 \mathrm{ml}$ for the IDEIA.

Swab specimens were also collected from 202 patients attending a social hygiene clinic in Hong Kong between January and April 1993 irrespective of their clinical diagnosis. Three urethral/cervical swabs were collected from each patient. Gram smear of the discharge material was examined before being inoculated onto Modified Thayer Martin agar, incubated in a candle jar, and then transported daily to another laboratory for culture. Swabs collected for the present study were placed in the transport medium and frozen at $-20^{\circ} \mathrm{C}$ until use.
\end{abstract}

\section{$\begin{array}{lllllllllllll}1 & 2 & 3 & 4 & 5 & 6 & 7 & 8 & 9 & 10 & 11 & 12 & 13\end{array}$}

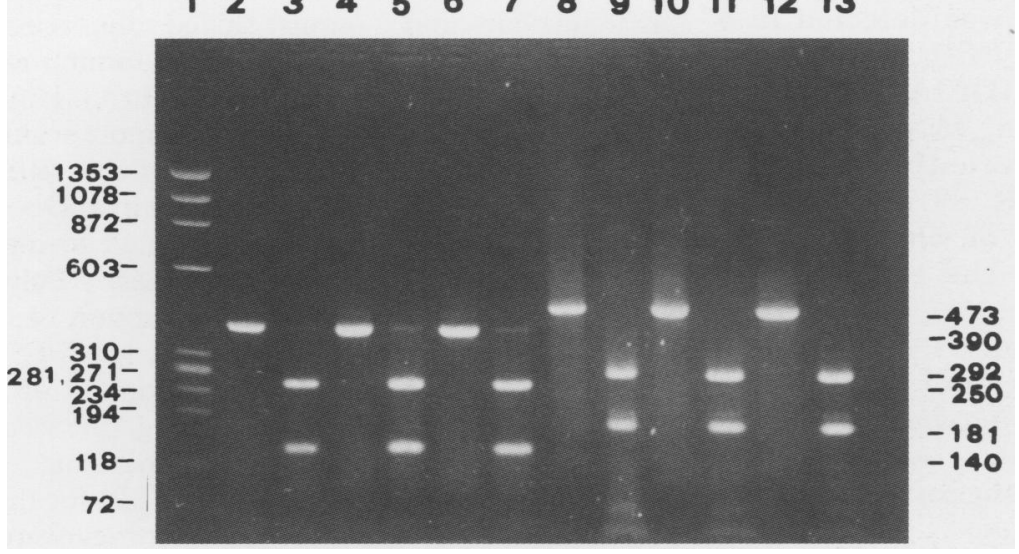

Figure 1 Endonuclease digestion of PCR products. Lane 1, DNA size marker oX174HaeIII; lanes 2, 4, and 6, PCR products (390 base pairs) of $N$ gonorrhoeae; lanes 3, 5 , and 7, DNA fragments (250 and 140 base pairs) of MspI digested PCR products; lanes 8, 10, and 12, PCR products (473 base pairs) of $C$ trachomatis; lanes 9,11 , and 13, DNA fragments (292 and 181 base pairs) of TaqI digested PCR products.
One swab was used for the Gonozyme assay and DNA extraction for the PCR assay, while the other was used for the IDEIA.

The Gonozyme assay was carried out according to the manufacturer's instructions. For the IDEIA, those swabs collected from China were already suspended in Gonozyme specimen dilution buffer. The tubes were vortex mixed for at least one minute and $200 \mu \mathrm{l}$ of the suspending solution was centrifuged at high speed $(13000 \mathrm{rpm})$ for 10 minutes. Supernatant fluid was then aspirated and the pellet was resuspended in freshly prepared IDEIA working transport medium (supplied with the kit). Swabs collected in Hong Kong for IDEIA were suspended in IDEIA working transport medium and were vortexed for at least one minute. Subsequent procedures were carried out according to the manufacturer's instructions.

\section{DNA AMPLIFICATION}

The collected swabs were suspended in Gonozyme specimen dilution buffer. They were vortexed for at least one minute before $500 \mu \mathrm{l}$ of each specimen was aspirated and centrifuged at high speed $(13000 \mathrm{rpm})$ for 10 minutes. The supernatant was removed and the pellet was resuspended in $500 \mu \mathrm{l}$ sterile distilled water and re-centrifuged. The pellet was then suspended in $50 \mu \mathrm{l} 1 \times$ PCR buffer $(50 \mathrm{mM} \mathrm{KCl}$, $10 \mathrm{mM}$ TRIS, $\mathrm{pH} 8 \cdot 3,100 \mu \mathrm{g} / \mathrm{ml}$ bovine serum albumin, $1.5 \mathrm{mM} \mathrm{MgCl}{ }_{2}$ ) with $4.5 \%$ Tween 20 and proteinase $\mathrm{K}(200 \mu \mathrm{g} / \mathrm{ml})$. The suspension was incubated at $50-60^{\circ} \mathrm{C}$ for one hour, then heated to $95^{\circ} \mathrm{C}$ for 10 minutes to inactivate proteinase $K$. The suspension was then ready for the PCR assay or kept at $-70^{\circ} \mathrm{C}$ for future use.

\section{PCR ASSAY FOR N GONORRHOEAE}

PCR amplification for $N$ gonorrhoeae was performed with the Hol and Ho3 primers according to the protocol described by Ho et al. ${ }^{6}$ The amplified product was a 390 base pair fragment. This fragment, if digested with 5 units of MspI (Boehringer, Mannheim, Germany) at $37^{\circ} \mathrm{C}$ for two hours, gives two base pair fragments (250 and 140) (fig 1).

PCR ASSAY FOR C TRACHOMATIS

DNA amplification for $C$ trachomatis was carried out according to the protocol described by Østergaard et al. ${ }^{16}$ The second primer set CT2A (5'-CGCATGCAAGATATCGAGTATGCGTTGTTAGG-3') and CT2B (5'-GACCGGCCTCTAGCGCTGCG-3') was used. The amplified product was 473 base pairs long. This fragment, when digested with TaqI (Boehringer) at $37^{\circ} \mathrm{C}$ for two hours, gives two base pair fragments (292 and 181) (fig 1).

\section{DUPLEX PCR ASSAY}

When comparing the cycle parameters for the respective PCR assays for $N$ gonorrhoeae and $C$ trachomatis, the temperatures used for the two assays were similar but the duration of each 
Table 1 Performance of duplex PCR for the detection of $N$ gonorrhoeae using the Gonozyme assay and culture as standards

\begin{tabular}{|c|c|c|c|c|c|c|c|c|c|c|}
\hline & \multicolumn{5}{|c|}{ Gonozyme assay } & \multicolumn{5}{|l|}{ Culture } \\
\hline & \multicolumn{2}{|l|}{ Positive } & \multicolumn{2}{|c|}{ Negative } & \multirow[b]{2}{*}{ Total } & \multicolumn{2}{|l|}{ Positive } & \multicolumn{2}{|c|}{ Negative } & \multirow[b]{2}{*}{ Total } \\
\hline & China & Hong Kong & China & Hong Kong & & China & Hong Kong & China & Hong Kong & \\
\hline $\begin{array}{l}\text { PCR positive } \\
\text { PCR negative }\end{array}$ & $\begin{array}{r}177 \\
0\end{array}$ & $\begin{array}{r}46 \\
0\end{array}$ & $\begin{array}{r}0 \\
26\end{array}$ & $\begin{array}{r}0 \\
156\end{array}$ & $\begin{array}{l}223 \\
182\end{array}$ & $\begin{array}{r}139^{*} \\
3^{* *}\end{array}$ & $\begin{array}{r}19 \\
0\end{array}$ & $\begin{array}{l}0 \\
15^{* *}\end{array}$ & $\begin{array}{r}27 \\
156\end{array}$ & $\begin{array}{l}185 \\
174\end{array}$ \\
\hline Total & \multicolumn{2}{|c|}{223} & \multicolumn{2}{|c|}{182} & 405 & \multicolumn{2}{|c|}{161} & \multicolumn{2}{|c|}{198} & 359 \\
\hline
\end{tabular}

*All tested positive with the Gonozyme assay; ** all tested negative with the Gonozyme assay.

Table 2 Performance of duplex PCR for the detection of $C$ trachomatis using IDEIA as the standard

\begin{tabular}{|c|c|c|c|c|c|}
\hline & \multicolumn{2}{|c|}{$I D E I A$ positive } & \multicolumn{2}{|c|}{ IDELA negative } & \multirow[b]{2}{*}{ Total } \\
\hline & China & Hong Kong & China & Hong Kong & \\
\hline $\begin{array}{l}\text { PCR positive } \\
\text { PCR negative }\end{array}$ & $\begin{array}{r}28 \\
0\end{array}$ & $\begin{array}{r}25 \\
0\end{array}$ & $\begin{array}{r}19 \\
156\end{array}$ & $\begin{array}{r}9 \\
168\end{array}$ & $\begin{array}{r}81 \\
324\end{array}$ \\
\hline Total & \multicolumn{2}{|c|}{53} & \multicolumn{2}{|c|}{352} & 405 \\
\hline
\end{tabular}

cycle was longer for $C$ trachomatis amplification. The cycle conditions for $C$ trachomatis were tested on known gonococcal positive specimens using $\mathrm{Ho} 1$ and $\mathrm{Ho} 3$ as primers and all tested specimens showed the expected 390 base pair fragment with no apparent diminished sensitivity. For the duplex PCR assay, therefore, cycle parameters used for PCR assays of $C$ trachomatis were used. For the 203 specimens collected in China, 177 specimens were $N$ gonorrhoeae positive on both the duplex PCR and single primer pair PCR. For $C$ trachomatis, however, 47 were positive on the single primer pair PCR while only 40 were positive on duplex PCR. Under the conditions used, there seemed to be competition between the gonococcal and chlamydial primers, with the chlamydial primers appearing to be less competitive. To optimise the assay conditions, the concentrations of the four nucleotides (dNTPs) were each increased from 200 to $300 \mu \mathrm{M}$ and the amount of Taq polymerase was increased from $2 \cdot 5$ to 4.0 units. Ten cycles were first run with the

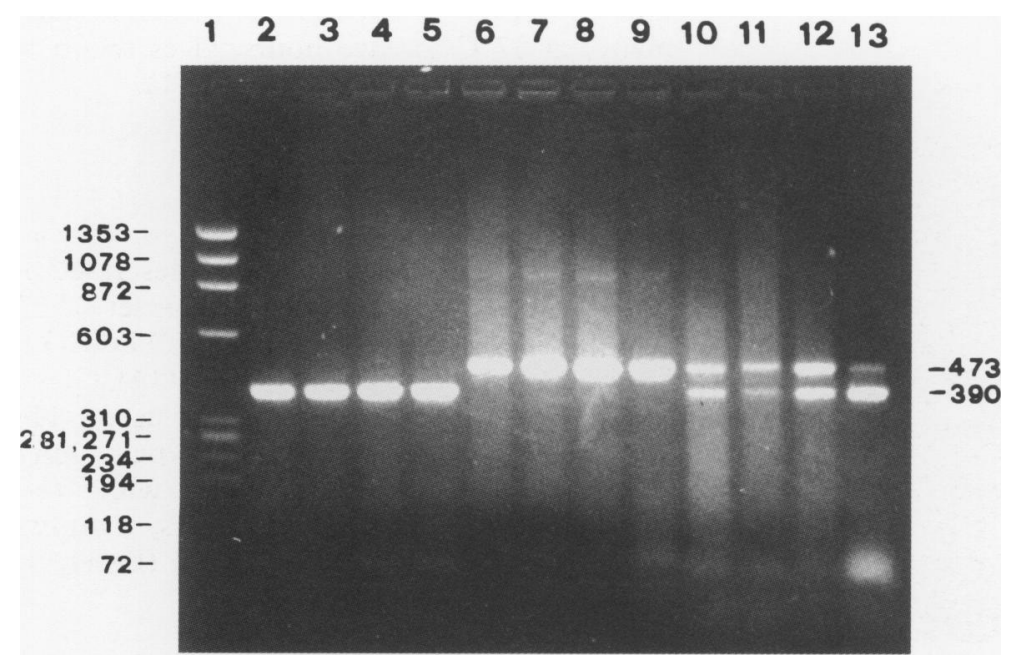

Figure $2 P C R$ results of representative samples from patients positive for $N$ gonorrhoeae and $C$ trachomatis infection. Lane 1, DNA size marker oX174-HaeIII; lanes 2-5, PCR products (390 base pairs) of clinical samples containing $N$ gonorrhoeae; lanes $6-9, P C R$ products ( 473 base pairs) of clinical samples containing $C$ trachomatis; lanes 10-13, $P C R$ products of clinical samples containing both $N$ gonorrhoeae and $C$ trachomatis. primer set CT2A and CT2B to increase the number of available templates and hence competitiveness for the subsequent cycles. This was then followed by a further 35 cycles after the addition of the Hol and Ho3 primer set. With these new cycle parameters and assay conditions, all of the seven previously negative specimens were positive. These assay conditions were then used for specimens collected in Hong Kong and the results were satisfactory. All PCR assays were carried out with usual precautions taken to prevent cross contamination. Positive controls, containing target DNA sequences of control strains of $N$ gonorrhoeae and $C$ trachomatis and a negative control-that is, a reagent control, containing all the necessary components for PCR except template DNA, were included in each run.

\section{Results}

Results of the PCR for $N$ gonorrhoeae compared with those for the Gonozyme assay and culture are presented in table 1 . The results of PCR and IDEIA for $C$ trachomatis are shown in table 2. The duplex PCR results compared well with the single PCR assays. Moreover, when coinfection occurred, as indicated by the Gonozyme and IDEIA PCRs, two bands, 390 and 473 base pairs long, respectively, were detected in all cases (fig 2).

There were three swab specimens from the China series which were culture positive but PCR negative for $N$ gonorrhoeae. A previous study $^{19}$ has demonstrated that plasmid free strains synthesise the polypeptide product of the $c p p B$ gene. However, successful use of the $\mathrm{Ho} 1$ and $\mathrm{Ho} 3$ primers with plasmid free strains has not been conclusively demonstrated as yet. PCR was therefore performed on gonococci from the three cultures in question, which all produced a 390 base pair fragment (fig 2), indicating that the negative PCR assay results were not caused by the absence of the $c p p B$ gene. In the case of the China specimens the culture swab was always taken first. It seems likely therefore that these three negative results resulted from the second swab failing to collect sufficient antigen or DNA for detection by PCR and the Gonozyme assay, respectively.

\section{Discussion}

The results with the Hong Kong series were somewhat different with respect to the proportion of results on culture, although the results obtained with the Gonozyme assay and PCR are comparable (table 1). This was probably because the samples were transported to 
a remote laboratory for incubation, resulting in a low success rate.

In contrast to $N$ gonorrhoeae, duplex PCR for $C$ trachomatis was significantly more sensitive than the immunological method-that is, the IDEIA. It is possible, however, that PCR positive results obtained in IDEIA negative samples could be false positives. However, the specimens were all from symptomatic individuals from a high risk population. Precautions against cross contamination were adequate as none of the patients negative for $N$ gonorrhoeae infection on the Gonozyme assay were positive on PCR. Therefore, PCR is significantly more sensitive for the detection of $C$ trachomatis than IDEIA.

The specimens from the China series were highly selected in that they were all showed Gram negative intracellular diplococci or numerous pus cells on initial Gram smears. This probably explains the much higher incidence of positive results in that group compared with the Hong Kong group.

The results of this study suggest that duplex PCR is a useful, reasonably rapid, and costeffective test for detecting $N$ gonorrhoeae and $C$ trachomatis, especially where sampling is carried out in locations remote from laboratory facilities. Culture methods for $C$ trachomatis are time-consuming and expensive, and the ability to screen for two pathogens in a single test is clearly advantageous. The results of this study suggest that it may be possible to develop multiple PCRs for urethral pathogens. Possible differences in competitiveness between primer pairs must be considered when establishing the parameters for duplex and multiple PCR assays. PCR, however, as with the immunological methods, does not provide information on antibiotic sensitivities or permit the detection of immunological markers and therefore cannot be a substitute for culture.

We would like to take this opportunity to thank Dr Wong Wai Ping and Mr Feng Weng Guang for their kind assistance in collection of specimens and for provision of gonococcal culture collection of specimens and for provision of gonococcal culture Hong Kong and the Sexually Transmitted Diseases Clinic in
Guangzhou, China, respectively. This paper was supported by the Research Committee of Hong Kong Polytechnic.

1 Morello JA, Janda WM, Doern GV. Neisseria and Branhamella. In: Balows A, Hausler WJ, Herrmann KL, Isenhamella. In: Balows A, Hausler WJ, Herrmann KL, Isenberg HD, Shadomy HJ, eds. Manual of clinical microb

2 Mirrett S, Reller LB, Knapp JS. Neisseria gonorrhoeae strains inhibited by vancomycin in selective media and correlation with auxotype. $\mathcal{F}$ Clin Microbiol 1981;14:94-9.

3 Danielsson D, Moi H, Forslin L. Diagnosis of urogenital gonorrhoea by detecting gonococcal antigen with a solid phase enzyme immunoassay (Gonozyme). 7 Clin Pathol 1983;36:674-7.

4 Roongpisuthipong A, Lewis JS, Kraus SJ, Morse SA. Gonococcal urethritis diagnosed from enzyme immunoassay of coccal urethritis diagnosed from enzyme immune sediment. Sex Trans Dis 1988;15:192-5.

5 Schachter J, McCormack WM, Smith RF, Parks RM, Bailey R, Ohlin AC. Enzyme immunoassay for diagnosis of gonorrhoea. $\mathfrak{F}$ Clin Microbiol 1984;19:57-9.

6 Ho BSW, Feng WG, Wong KC, Egglestone SI. Polymerase chain reaction for the detection of Neisseria gonorrhoeae in clinical samples. $\mathcal{f}$ Clin Pathol 1992;45:439-42.

7 Grayston JT, Wang S. New knowledge of Chlamydiae and disease they cause. $\mathcal{F}$ Infect $D$ is $1975 ; 132: 87-105$.

8 T'ang FF, Chang HL, Hung YT, Wang KC. Studies on the etiology of trachoma with special reference to isolation of the virus in chick embryo. Chin Med $¥$ 1957;75:429-47.

9 Tam MR, Stephens RS, Mardh P-A, Holmes KK, et al, Tam MR, Stephens RS, Mardh P-A, Holmes KK, et al,

10 Caul EO, Paul ID, Milne JD, Crowley T. Non-invasive sampling method for detection Chlamydia trachomatis. Lancet 1988;ii:1246-7.

11 Chernesky M, Castriciano S, Sellors J, Stewart I, Cunningham I, Landis S, et al. Detection of Chlamydia trachomatis antigens in urine as an alternative to swabs and cultures. F Infect Dis 1990;161:124-6.

12 Paul ID, Crowley T, Milne JD, Caul EO. A comparison of urine and urethral swabbing for the diagnosis of $\mathrm{C}$. trachomatis infection in males. Serodiagn Immuno Infect Dis 1990;4:473-80.

13 Crowley T, Milne D, Arumainayagam JT, Paul ID, Caul EO. The laboratory diagnosis of male Chlamydia trachomatis infections - a time for change? $₹$ Infect 1992;25(Suppl I): infection

14 Paul ID, Caul EO. Evaluation of three Chlamydia trachomatis immunoassays with an unbiased, noninvasive clinical sample. f Clin Microbiol 1990;28:220-2.

15 Miyashita N, Matsumoto A. Establishment of a particlecounting method for purified elementary bodies of Chlamydiae and evaluation of sensitivities of the IDEIA Chlamydia kit and DNA probe by using the purified elementary bodies. F Clin Microbiol 1992;30:2911-6.

16 Østergaard L, Birkelunds S, Christiansen G. Use of polymerase chain reaction for detection of Chlamydia trachmerase chain reaction for detection of Ch.

$17 \mathrm{Wu}$ CH, Lee MF, Yin SC, Yang DM, Cheng SF. Comparison of polymerase chain reaction, monoclonal antibody based immunoassay, and cell culture for detection of Chlamydia trachomatis in genital specimens. Sex Trans Dis 1992;19:193-7.

18 Claas HCJ, Wagenvoort JHT, Niesters HGM, Tio TT, Van Rijsoort-Vos JH, Quint WGV. Diagnostic value of the polymerase chain reaction for Chlamydia detection as determined in a follow-up study. 7 Clin Microbiol 1991; 29:42-5.

19 Hagblom P, Korch C, Jonsson A, Normark S. Intragenic variation by site-specific recombination in the cryptic plasmid of Neisseria gonorrhoeae. $\mathcal{F}$ Bacteriol 1986;167: 213-17. 